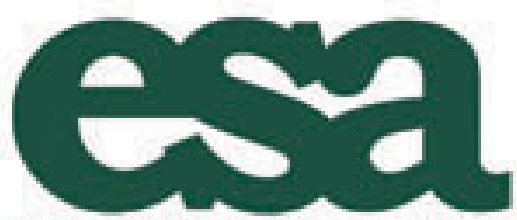

Promoting the Science of Ecology

Functional Response of Herbivores in Food-Concentrated Patches: Tests of a Mechanistic Model Author(s): John E. Gross, Lisa A. Shipley, N. Thompson Hobbs, Donald E. Spalinger, Bruce A. Wunder

Source: Ecology, Vol. 74, No. 3 (Apr., 1993), pp. 778-791

Published by: Ecological Society of America

Stable URL: http://www.jstor.org/stable/1940805

Accessed: 29/01/2009 08:43

Your use of the JSTOR archive indicates your acceptance of JSTOR's Terms and Conditions of Use, available at http://www.jstor.org/page/info/about/policies/terms.jsp. JSTOR's Terms and Conditions of Use provides, in part, that unless you have obtained prior permission, you may not download an entire issue of a journal or multiple copies of articles, and you may use content in the JSTOR archive only for your personal, non-commercial use.

Please contact the publisher regarding any further use of this work. Publisher contact information may be obtained at http://www.jstor.org/action/showPublisher?publisherCode=esa.

Each copy of any part of a JSTOR transmission must contain the same copyright notice that appears on the screen or printed page of such transmission.

JSTOR is a not-for-profit organization founded in 1995 to build trusted digital archives for scholarship. We work with the scholarly community to preserve their work and the materials they rely upon, and to build a common research platform that promotes the discovery and use of these resources. For more information about JSTOR, please contact support@jstor.org. 


\title{
FUNCTIONAL RESPONSE OF HERBIVORES IN FOOD-CONCENTRATED PATCHES: TESTS OF A MECHANISTIC MODEL ${ }^{1}$
}

\author{
JoHN E. Gross \\ Natural Resource Ecology Laboratory, Colorado State University, Fort Collins, Colorado 80523 USA \\ LiSA A. SHIPLEY \\ Texas Agricultural Experiment Station, Texas A\&M University, \\ 1619 Garner Field Road, Uvalde, Texas 78801 USA
}

N. ThOMPSON HoBBS

Natural Resource Ecology Laboratory, Colorado State University, Fort Collins, Colorado 80523 USA and Mammals Research Section, Colorado Division of Wildlife, 317 West Prospect, Fort Collins, Colorado 80526 USA

\author{
DONALD E. SPALINGER \\ Texas Agricultural Experiment Station, Texas A\&M University, \\ 1619 Garner Field Road, Uvalde, Texas 78801 USA \\ BRUCE A. WUNDER \\ Department of Biology, Colorado State University, Fort Collins, Colorado 80523 USA
}

\begin{abstract}
Type II functional responses are frequently observed in herbivores feeding in patches where plants are concentrated in space. We tested a mechanistic model of regulation of intake rate of herbivores foraging in food-concentrated patches (Laca and Demment 1992, Spalinger and Hobbs 1992) that accounts for asymptotic, Type II responses. The model is based on the hypothesis that competition between cropping and chewing regulates instantaneous intake rate in response to changes in the size of bites obtained by the forager. We tested this hypothesis and examined the ability of our model to account for observations of intake rate of 12 species of mammalian herbivores ranging in body mass over 4 orders of magnitude.

We measured short-term intake rates of mammalian herbivores feeding in hand-assembled patches of plants. We varied bite size by changing plant height and density in patches offered to herbivores, and observed dry matter intake rates in response to this variation. Averaged across species, our model accounted for $77 \%$ of the variance in food intake rate $(P<.001$ for all species). Predictions of maximum intake rate closely resembled observations of processing capacity, demonstrating that processing rather than cropping sets an upper limit on short-term intake. Tests of model mechanisms provided strong support for the hypothesis that competition between cropping and chewing is responsible for the Type II functional response seen in herbivores feeding in food-concentrated patches. The model was able to consistently predict intake rates observed in 16 previous studies. These results indicate that plant characteristics regulating bite size (e.g., leaf size and geometry, spinescence) frequently control instantaneous rates of food intake by mammalian herbivores.
\end{abstract}

Key words: bite size; browsing; disc equation; foraging; functional response; grazing; handling time; herbivory; intake rate; mammal; patch; plant-animal interaction.

\section{INTRODUCTION}

Solomon (1949) and Holling (1959, 1965) distinguished between the numerical response of animals and their functional response. In one form or another, equations representing these responses play a central role in most contemporary models of predator-prey and plant-herbivore interactions (Hassell 1978, Caughley 1982, Edelstein-Keshet 1986, Elsen et al. 1988, Gren-

\footnotetext{
${ }^{1}$ Manuscript received 24 December 1991; revised 26 May 1992; accepted 17 June 1992.
}

fell 1992). However, despite its general importance in animal ecology, most work on functional response has focused specifically on predators and parasitoids (reviewed by Schoener 1971, Pyke 1984, Stephens and Krebs 1986). During the last decade interest in developing foraging theory specific to herbivores has increased dramatically (Owen-Smith and Novellie 1982, Illius and Gordon 1987, Lundberg 1988, Ungar and Noy-Meir 1988, Åström et al. 1990, Lundberg and Åström 1990, Laca and Demment 1992, Spalinger and Hobbs 1992). We believe that the development of this theory is hampered by the absence of tested models of 
functional response that are faithful to the unique features of foraging by herbivores.

Unlike most predators, herbivores often forage in patches where foods are highly concentrated in space and are readily apparent to the forager. Grass swards and stands of leafy shrubs offer examples of such food patches. Under these circumstances, the density of "prey" approaches infinity, i.e., one prey item immediately adjoins another. When this is the case, traditional models of functional response predict that intake is simply the reciprocal of handling time, which is parsimoniously assumed to be a constant function of prey size. For example, the disc equation (Holling 1959) predicts the number of prey consumed per unit time as a function of prey density. Prey consumption varies with prey handling time and predator searching efficiency,

$$
N=\frac{A D T}{1+A H D},
$$

where $N=$ the number of prey captured, $A=$ the predator's searching efficiency (in square metres per minute), $D=$ prey density (number per square metre), $T=$ duration of foraging (in minutes), and $H=$ handling time of prey item (minutes per prey). If we define $N$ as the number of bites of plant tissue (i.e., bites = prey) taken by an herbivore during a given time interval $(T)$, we can obtain a form that specifies the herbivore's instantaneous rate of intake of plant mass $(I$, in grams per minute) by multiplying the disc equation by bite size $(S$, in grams per bite) and dividing by foraging time $(T)$ :

$$
I=\frac{A D}{1+A H D} \cdot S
$$

When prey are infinity dense, we have

$$
\lim _{D \rightarrow \infty} \frac{A D}{1+A H D} \cdot S=S / H=I,
$$

which predicts that the intake rate of herbivores feeding in food-saturated patches should increase as a linear function of bite size (i.e., a Type I functional response). This prediction is contradicted by empirical evidence showing that intake rate of herbivores increases asymptotically as bite size increases (i.e., a Type II functional response; Allden and Whittaker 1970, Wickstrom et al. 1984, Hudson and Watkins 1986, Hudson and Frank 1987, Spalinger et al. 1988). Explaining this Type II behavior requires a model that allows handling time $(H)$ to change dynamically as bite size changes.

The need for a dynamic representation of handling time motivated us to develop a new model of functional response of herbivores foraging in food-concentrated patches (Spalinger and Hobbs 1992). We began by defining a bite as a mass of plant tissue that an herbivore can remove from the plant with a single jaw movement. The size of the bite cropped $(S)$ is determined by the interaction between the geometry of the animal's mouth (Illius and Gordon 1987, Janis and Ehrhardt 1988) and the geometric arrangement of plant tissue in space (Stobbs 1973, Chacon and Stobbs 1976, Burlison et al. 1991, Penning et al. 1991, Laca et al. 1992). If cropping rate ( $B$, in bites per minute) were a constant function of bite size, then intake rate would be directly proportional to bite size, as suggested by the disc equation. Alternatively, we hypothesized (Spalinger and Hobbs 1992) that cropping rate must decline with increasing bite size because larger bites require an herbivore to invest more effort in masticating a bite to prepare it for swallowing, and because these chewing movements cannot occur simultaneously with cropping movements (Ardran et al. 1958, Greaves 1978, Fortelius 1985). Based on these ideas, we have shown (Spalinger and Hobbs 1992) that cropping rate, (and thus handling time), can be predicted as

$$
\frac{1}{H}=B=\frac{R_{\max }}{R_{\max } \bar{h}+S},
$$

where $R_{\max }$ is the maximum rate of processing of plant tissue in the mouth (in grams per minute) that would occur in the absence of cropping, and $\bar{h}$ is the average time (in minutes per bite) required to crop a single bite in the absence of chewing. It follows (Spalinger and Hobbs 1992) that intake rate of herbivores feeding on spatially concentrated foods can be represented as an asymptotic function of bite size:

$$
I=\frac{R_{\max } S}{R_{\max } \bar{h}+S}
$$

Thus, Eq. 5 represents the hypothesis that competition between cropping and chewing is responsible for the Type II functional response frequently seen in herbivores feeding in food-concentrated patches (Allden and Whittaker 1970, Wickstrom et al. 1984, Hudson and Watkins 1986, Hudson and Frank 1987, Spalinger et al. 1988). A similar model has been developed independently by Laca and Demment (1992), and Spalinger and Hobbs (1992) derived explicit conditions defining when these models should apply.

Here, we report experimental tests of our model of functional response (Eq. 5) for mammalian herbivores differing in body size and feeding style. We offer tests of the model's mechanism and discuss the significance of that mechanism for understanding foraging behavior of herbivores.

\section{Materials AND Methods}

\section{Experimental manipulation of bite size}

We observed changes in food intake rate ( $I$, Eq. 5) that occurred in response to changes in bite size ( $S$, Eq. 5) of 12 species of herbivores spanning 4 orders of magnitude in body mass (Table 1). The animals in our experiments represented a variety of feeding styles, dentition patterns, and digestive adaptations. Differences in bite size were imposed by varying the size of 
TABLE 1. Species used in tests of the functional response model.

\begin{tabular}{|c|c|c|c|c|c|c|c|c|}
\hline Species & Mass (kg) & $(n)^{*}$ & $\begin{array}{l}\text { Origin/ } \\
\text { rearing } \dagger\end{array}$ & $\begin{array}{c}\text { Molar } \\
\text { dentition }\end{array}$ & $\begin{array}{l}\text { Feeding } \\
\text { style }\end{array}$ & Siteł & $\begin{array}{l}\text { Dis- } \\
\text { tance } \\
(\mathrm{cm})\end{array}$ & $\begin{array}{l}\text { No. } \\
\text { trials }\end{array}$ \\
\hline \multicolumn{9}{|l|}{ Collared lemming } \\
\hline (Dicrostonyx groenlandic & 0.05 & (13) & $\mathrm{C} / \mathrm{M}$ & hypsodont & grazer & $\mathrm{CO}$ & 1 & 57 \\
\hline \multicolumn{9}{|l|}{ Black-tailed prairie dog } \\
\hline (Cynomys ludovicianus) & 0.75 & $(3 / 2)$ & $\mathrm{W} / \mathrm{M}$ & hypsodont & mixed & $\mathrm{CO}$ & 4.5 & 108 \\
\hline Domestic rabbit (Oryctolagus cuniculus) & 2.9 & $(2 / 3)$ & $\mathrm{C} / \mathrm{M}$ & hypsodont & grazer & TX & 9 & 125 \\
\hline Collared peccary (Tayassu tajacu) & 27.2 & $(3 / 0)$ & $\mathrm{C} / \mathrm{M}$ & bunodont & concentrate\| & TX & 9 & 124 \\
\hline \multicolumn{9}{|l|}{ White-tailed deer (fawn) } \\
\hline (Odocoileus virginianus) & 25.5 & $(2 / 2)$ & $\mathrm{C} / \mathrm{B}$ & selenodont & mixed & TX & 18 & 90 \\
\hline White-tailed deer (adult) & 45.0 & $(1 / 3)$ & $\mathrm{C} / \mathrm{B}$ & selenodont & mixed & TX & 18 & 67 \\
\hline Axis deer (Axis axis) & 53.0 & $(0 / 3)$ & W/B & selenodont & grazer & $\mathrm{TX}$ & 18 & 62 \\
\hline Caribou (Rangifer tarandus) & 104 & $(2 / 0)$ & $\mathrm{W} / \mathrm{B}$ & selenodont & mixed & WA & 18 & 46 \\
\hline Grizzly bear (Ursus arctos) & 161 & $(2 / 3)$ & $\mathrm{W} / \mathrm{M}$ & bunodont & omnivore & WA & 18 & 36 \\
\hline Elk (Cervus eleaphus) & 266 & $(0 / 3)$ & $\mathrm{C} / \mathrm{B}$ & selenodont & grazer & $\mathrm{CO}$ & 10 & 46 \\
\hline Moose (Alces alces) & 309 & $(1 / 1)$ & $\mathrm{W} / \mathrm{B}$ & lophodont & grazer & WA & 18 & 43 \\
\hline Horse (Equus caballus) & 432 & $(3 / 0)$ & $\mathrm{C} / \mathrm{M}$ & lophodont & grazer & TX & 18 & 41 \\
\hline Cow (Bos taurus) & 548 & $(2 / 2)$ & $\mathrm{C} / \mathrm{M}$ & lophodont & grazer & $\mathrm{TX}$ & 18 & 73 \\
\hline
\end{tabular}

* Number of individuals (male/female). All male horses, caribou, and cattle were castrated. Sex of lemmings unknown.

$+\mathrm{C}=$ captive born, $\mathrm{W}=$ wild born, $\mathrm{M}=$ maternal raised, $\mathrm{B}=$ bottle (human) reared

$\ddagger \mathrm{CO}=$ Fort Collins, Colorado; $\mathrm{TX}=$ Uvalde, Texas; WA = Pullman, Washington.

$\S$ Distance between bites.

\| Concentrate selector (e.g., cactus fruits, pods from legumes).

plants offered to animals in patches (Black and Kenney 1984, Spalinger et al. 1988) that were assembled as follows. We offered animals preweighed amounts of fresh alfalfa (Medicago sativa) anchored to plywood boards $(25.5 \mathrm{~cm} \times 28.5 \mathrm{~cm} \times 12.7 \mathrm{~mm}$ thick for prairie dogs, and $61 \mathrm{~cm} \times 61 \mathrm{~cm} \times 19 \mathrm{~mm}$ thick for all other species except lemmings). We used alfalfa because it was palatable to a broad range of herbivores and was consistent in quality among study locations. Holes were drilled in plywood boards to accept alfalfa stems or petioles, which were firmly held with rubber stoppers inserted from the bottom of the board. Plants were uniformly spaced $4.5,9,10$, or $18 \mathrm{~cm}$ apart to scale plant distribution to the size of the animal being observed (Table 1). To complete the patch, boards were bolted to frames $1.2 \times 2.4 \mathrm{~m}$ (for prairie dogs $0.31 \times$ $1.22 \mathrm{~m}$ ) to form a surface where the animal foraged. Because of their small size, lemmings required a different experimental apparatus. Lemmings were offered leaves placed at $1-\mathrm{cm}$ intervals in plastic clips (commonly sold as binders for report covers). These clips were roughly triangular in cross section, $13 \mathrm{~mm}$ high, $5 \mathrm{~mm}$ wide at the base, and $280 \mathrm{~mm}$ long. Petioles were securely held by pressure exerted at the apex of the clip. Clips were attached to an acrylic-fronted runway $9 \mathrm{~cm}$ wide $\times 61 \mathrm{~cm}$ long.

Hereafter, we will refer to plant size (in grams per plant) as the mass of plant tissue anchored at a single location in a patch, and bite size ( $S$, in grams per bite) as the mass of tissue removed from the plant by a single cropping motion of an herbivore. When animals consumed the entire plant from a single location, then plant size equalled bite size. We varied plant size by changing height and bulk density of plants on the boards. In so doing, we were able to force a 10 -fold or greater difference in mass between the largest and smallest bites taken by each species.

\section{Behavioral measures}

We measured dry matter intake rates of 2-13 individuals of each species (Table 1) feeding in artificial patches during foraging trials conducted during September 1990 through September 1991. All animals were habituated to the experimental protocols before trials were initiated. For each trial, a single animal was released into a patch consisting of plants of roughly equal size. As the animal foraged, we counted the number of bites cropped and recorded the elapsed time of active foraging. We used video tapes of trials replayed in slow motion to enhance the accuracy of our counts of cropped bites.

Because we were interested in the maximum instantaneous intake rate achievable at a given bite size, trials were kept brief, typically lasting $\approx 1.5 \mathrm{~min}$. Moreover, species were fasted before observations were taken to assure a high level of interest in feeding. Food was withheld from rabbits and smaller species for 6-7 h before intake measurements. Larger species were fasted overnight $(12 \mathrm{~h})$. Otherwise, animals were allowed ad libitum access to a maintenance diet.

We estimated total dry matter intake during a trial as the difference between the dry mass of forage offered at the beginning of the trial and the dry mass remaining on the boards at the end of the trial. The amount of forage offered was determined by weighing the plant material before it was placed in patches. Upon completion of a trial, all plant remains were removed, dried to a constant mass in a convection or microwave oven, and weighed. Because orts were held firmly in place in the patch, we were able to collect all of the plant mass 
remaining at the end of a feeding trial. The average bite size consumed during each trial was determined by dividing total amount of forage removed (i.e., total intake) by the number of cropping bites observed during that trial.

All calculations were corrected for dry matter. Dry matter corrections were determined daily from several subsamples of offered material, and varied little among days or sites.

\section{Model tests}

We designed three model tests. First, we examined whether the model could provide a reasonable statistical fit to the data. Model parameters were estimated by nonlinear regression (SAS 1988), and the residuals were analyzed for a systematic lack of fit using a runs test (Sokal and Rohlf 1981). Values of $r^{2}$ for nonlinear regressions were calculated using corrected sums of squares (Motulsky and Ransnas 1987). We separately analyzed plant size and bite size as independent variables. Both quantities offer useful features in our analyses. Clearly, plant size ultimately controls bite size, while bite size is proximally responsible for the mechanism we propose (Eq. 5). Bite size is virtually impossible to measure directly, particularly for small animals. So, we estimated bite size indirectly as a ratio (total mass removed per total number of cropping bites). The numerator of this ratio was also present in the dependent variable, intake rate (total mass removed per time). Regression analyses based on ratios are controversial (Prairie and Bird 1989, Jackson and Somers 1991, Kenney 1991). So, we also analyzed our data by regressing intake rate against direct measurements of plant size, which shares no term in common with intake rate.

Examining statistical fit of a model to data provides an opportunity for the model to fail, but it does not validate mechanisms the model represents. To do so, we derived predictions from the model and compared those predictions with independent observations. Two predictions are central to our model. The first is that cropping motions of the jaw compete with chewing motions, thereby producing a decelerating rate of intake with increasing bite size. Second, the model predicts that the asymptotic maximum intake rate (i.e., $R_{\max }$ ) of herbivores feeding in food-concentrated patches is set by constraints on food processing in the mouth. We tested these predictions as follows.

The functional form of the competitive relationship between cropping and chewing is given by Eq. 4 . If the deceleration in intake rate in Eq. 5 is produced by competition between cropping and chewing, then cropping rate must decline asymptotically as bite size increases according to Eq. 4 (Spalinger and Hobbs 1992).

Our model (Eq. 5) also predicts that maximum instantaneous intake rate is set by a processing constraint, $R_{\max }$. In the absence of cropping, intake rate is theoretically limited only by the ability of the animal to masticate food sufficiently to render it suitable for swallowing. We estimated $R_{\max }$ (in grams per minute) directly as the product of chewing effort (grams per chew) and chewing frequency (in chews per minute):

$$
R_{\max }=C_{e} \times C_{f} .
$$

We defined a chew to consist of a single up and down cycle of the jaw terminating when the molars occluded. We observed chewing behavior using video tapes of feeding animals replayed in slow motion. Values for chewing effort $\left(C_{e}\right.$, Eq. 6) were obtained by dividing the total number of chews observed during a feeding trial by the dry mass of alfalfa consumed during the trial. Chewing frequencies $\left(C_{f}\right.$, Eq. 6$)$ were determined by counting at least five, consecutive, uninterrupted chews and dividing the number of chews by the time elapsed between the first and last chew. To test the proposed mechanism producing the asymptote in our model (Eq. 5), we compared observations of $R_{\max }$ (estimated as the product of $C_{e} \times C_{f}$ ) with predictions of $R_{\max }$ obtained from the statistical fit of Eq. 5 to intake rate data.

As a final model test, we compared published observations of intake rates for a variety of species to those predicted by Eq. 5 . To generate predicted intake rates, we first used body mass to match species represented in previous studies with species used in our experiments. We then substituted parameter values from the least squares fit of our functional response model (Eq. 5) to calculate a predicted intake rate for each bite size observed in previous studies. We excluded values only when the author noted that mechanical structures interfered with foraging (e.g., spines). We compared our model predictions against the observations of other workers.

\section{RESULTS}

Following a brief training period, all species readily consumed alfalfa offered in the foraging trials. Species used in our experiments consumed bites ranging in mass from $0.0004 \mathrm{~g}$ dry matter (lemming) to $8.1 \mathrm{~g}$ dry matter (cow). Analyses of the model for food-concentrated patches (Eq. 5) were based on 36-125 trials (Table $1 ;$ mean $=72$ trials/species). Each species consumed bites spanning at least an order of magnitude in mass, and plant size offered varied by $>2$ orders of magnitude for some species. We observed intake rates of $<0.03$ $\mathrm{g} / \mathrm{min}$ for lemmings to $>80 \mathrm{~g} / \mathrm{min}$ for cattle. Overall, estimates of maximum intake rate $\left(R_{\max }\right)$ increased with body mass (Tables 1 and 2), but $\bar{h}$ was independent of body mass, averaging $\approx 0.014 \mathrm{~min} /$ bite for all species. Details of our work on the allometry of model parameters will be reported elsewhere.

\section{Fidelity to observations}

As predicted by our model (Eq. 5), we observed an asymptotic relationship between plant size and intake rate of mammalian herbivores (Fig. 1). Plant size proved 

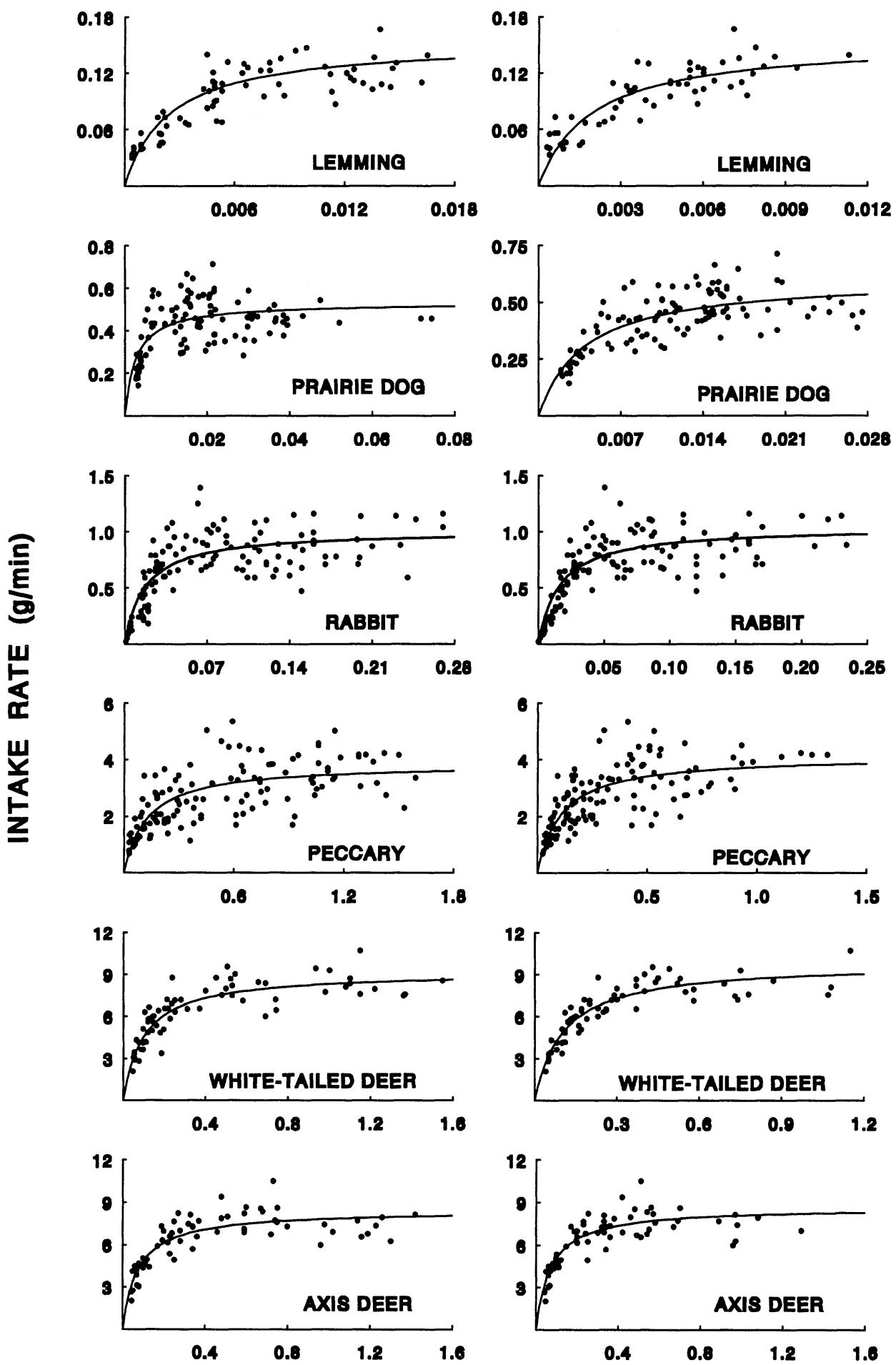

PLANT SIZE (g/plant)

BITE SIZE (g/blte)

FIG. 1. Intake rate of mammalian herbivores increased asymptotically as a function of plant size (left column on each page) and bite size. The solid line is nonlinear least squares fit of functional response model (see Eq. 5 in Introduction). Plant size is the mass of plant material available to the herbivore at a point in a hand-constructed patch. Bite size is the average mass of plant tissue cropped by an herbivore with a single cropping motion. When herbivores consumed an entire plant in a single bite then plant size equalled bite size. 

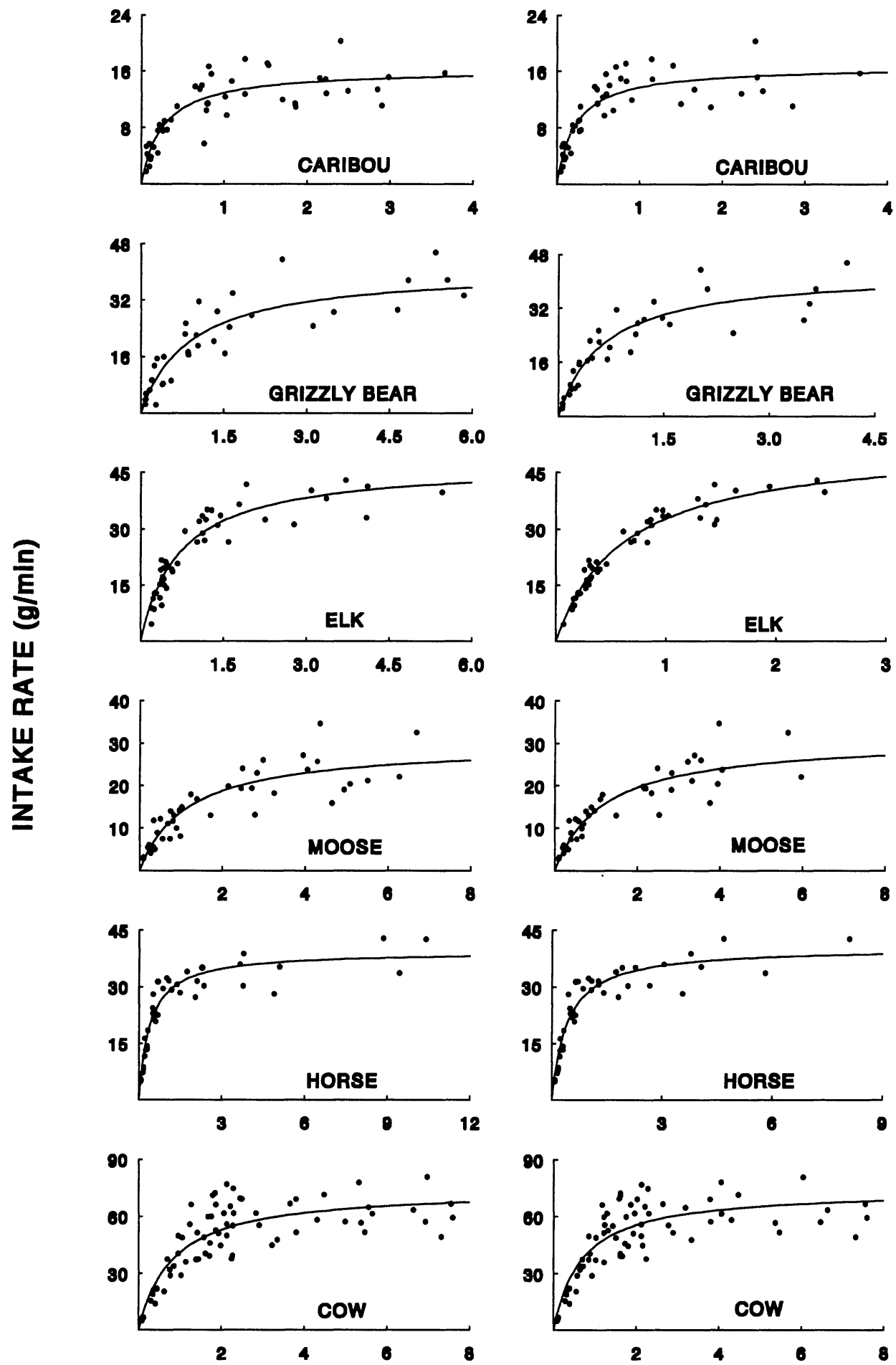

PLANT SIZE (g/plant)

BITE SIZE (g/bite)

Fig. 1. Continued. 
TABLE 2. Estimates of maximum processing rate $\left(R_{\max }\right)$ and cropping time $(\bar{h})$ from nonlinear regression of intake rate on bite or plant size (from Eq. 2$)$. All regressions are significant $(P<.001)$.

\begin{tabular}{|c|c|c|c|c|c|c|c|c|}
\hline \multirow[b]{2}{*}{ Species } & \multicolumn{4}{|c|}{ Bite size } & \multicolumn{4}{|c|}{ Plant size } \\
\hline & $\begin{array}{c}R_{\max } \\
(\mathrm{g} / \mathrm{min})\end{array}$ & $\bar{h}(\mathrm{~min} / \mathrm{bite})$ & $r^{2}$ & $\begin{array}{c}\text { Runs } \\
\text { test } \dagger\end{array}$ & $\begin{array}{c}R_{\max } \\
(\mathrm{g} / \mathrm{min})\end{array}$ & $\bar{h}(\mathrm{~min} / \mathrm{bite})$ & $r^{2}$ & Runs test \\
\hline Lemming & 0.15 & 0.013 & 0.74 & NS & 0.15 & 0.016 & 0.75 & NS \\
\hline Prairie dog & 0.61 & 0.006 & 0.59 & NS & 0.53 & 0.005 & 0.41 & NS \\
\hline Rabbit & 1.04 & 0.016 & 0.68 & $* *$ & 1.01 & 0.017 & 0.63 & $*$ \\
\hline Peccary & 4.14 & 0.026 & 0.57 & NS & 3.86 & 0.033 & 0.53 & NS \\
\hline White-tailed deer (fawn) & 6.32 & 0.010 & 0.73 & NS & 5.99 & 0.011 & 0.72 & NS \\
\hline White-tailed deer (adult) & 9.85 & 0.011 & 0.84 & $* *$ & 9.17 & 0.011 & 0.78 & NS \\
\hline Axis deer & 8.65 & 0.008 & 0.74 & NS & 8.42 & 0.009 & 0.73 & NS \\
\hline Caribou & 16.73 & 0.013 & 0.78 & NS & 16.29 & 0.016 & 0.75 & NS \\
\hline Grizzly bear & 43.06 & 0.015 & 0.87 & NS & 40.90 & 0.022 & 0.81 & NS \\
\hline Elk & 52.95 & 0.012 & 0.96 & NS & 47.41 & 0.015 & 0.89 & NS \\
\hline Moose & 31.11 & 0.038 & 0.83 & NS & 29.78 & 0.041 & 0.79 & NS \\
\hline Horse & 40.39 & 0.010 & 0.90 & NS & 39.31 & 0.010 & 0.89 & NS \\
\hline Cow & 74.16 & 0.009 & 0.75 & NS & 74.57 & 0.011 & 0.75 & NS \\
\hline
\end{tabular}

$* P<.05,{ }^{* *} P<.01, \mathrm{NS}=$ not significant.

$\uparrow$ Runs test on residuals (Sokal and Rohlf 1981:782).

to be an accurate predictor of intake rate, with an average corrected $r^{2}$ of $72 \%$ (Fig. 1; Table 2, all regressions were significant at $P \ll .001)$. We found a systematic lack of fit (i.e., a nonrandom distribution of residuals) in only one species (rabbits, runs test, $T_{s}=2.11, P<$ .05).

In general, using bite size $(S)$ as an independent variable improved the fit of the model (Table 2, Fig. 1). On average, $S$ accounted for $77 \%$ of the variance in intake rate (Table 2). A runs test performed on the residuals from Eq. 5 confirmed that there was no systematic lack of fit for 11 of the 13 species (Table 2). Asymptotes $\left(R_{\max }\right)$ estimated from nonlinear regression were within the measured range of observed asymptotic intake rates for all species except elk and peccaries. When large $(>2 \mathrm{~g})$ plants were offered to elk, they consistently chose bite sizes smaller than the plant size offered by cropping more than one bite from each plant. As a result, most points fell on the rapidly ascending portion of the functional response (Fig. 1), resulting in an unreasonably high estimate of $R_{\max }$. For some species (e.g., prairie dogs, axis deer) intake rate tended to decline slightly at very large bite sizes. This tendency may indicate a reduction in processing efficiency when bites become large (Dougherty et al. 1989b).

\section{Bite size and plant size}

When plant sizes were small, herbivores consumed the entire plant in a single bite. As a result, there was an isometric relationship between plant size and bite size consumed for small plants (Fig. 2). However, as plant size increased, we failed to detect a clearly demarcated upper limit to bite size for most species (Fig. 2). When we offered large plants (i.e., plants producing intake rates on the flat portion of the functional response curve), cows, horses, and rabbits often consumed bites much larger than would fit into their mouths with a single cropping motion. Animals consumed these bites by feeding the alfalfa stems directly to the molars via the diastema between the incisors and molars. This allowed them to crop bites that exceeded the dimensions of the mouth. In contrast, lemmings, elk, and prairie dogs tended to restrict bite size as plant size increased (for example, Fig. 2D). Body size and feeding style did not appear to influence these patterns.

\section{Tests of model mechanisms}

Consistent with our hypothesis, cropping rate declined at a decelerating rate as bite size increased for all species observed (Fig. 3).

Maximum intake rates calculated from direct measurements of chewing rate (chews per minute) and chewing effort (chews per gram; Table 3) compared favorably with $R_{\max }$ calculated from Eq. $5\left(r^{2}=0.98\right.$ for log-transformed values, $r^{2}=0.91$ for untransformed data; Fig. 4).

Our functional response model (Eq. 5) accounted for $83 \%$ of the variance in previously published observations of intake rate (Fig. $5, n=153, \log y=-0.085$ $+0.988 \log x, r^{2}=0.83, P<.001$, for untransformed data $\left.y=-2.09+1.07 x, r^{2}=0.86, P<.001\right)$. The largest residuals from the regression (circled points in Fig. 5) were obtained by recording pressure changes in a pneumatic bellows that encircled the jaw of feeding caribou (Trudell and White 1981). This device recorded both jaw and lip movements and may therefore have overestimated the number of prehending bites as we defined them.

\section{Discussion}

\section{Relationship to empirical studies of functional response}

Our observations of asymptotic intake rate $\left(R_{\max }\right)$ consistently exceeded intake rates reported for similar species of herbivores (Tables 2 and 4). However, we suggest that intake rates observed in many previous 

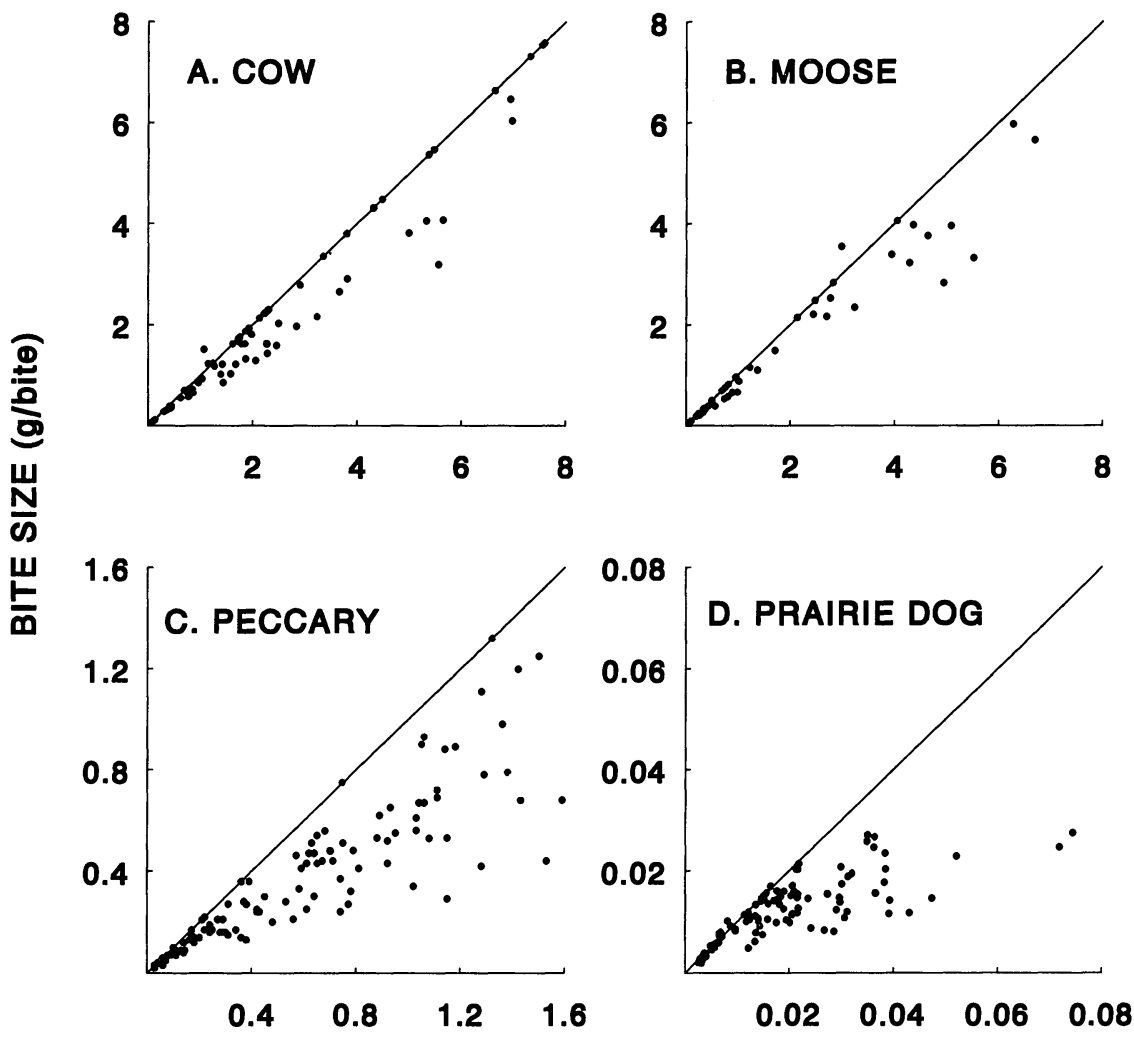

\section{PLANT SIZE (g/plant)}

FIG. 2. Plant size and bite size were not consistently related. — shows where plant and bite size are equal; $\bullet$ are observations of bite size for each plant size. We observed two types of cropping tactics. For some species, there was no clear upper limit to bite size (A, B). When plant sizes were large, these animals cropped bites that exceeded the volume of the mouth and "fed" plant tissue to the molars via the diastema between the incisors and the molars. Other species demonstrated stronger tendencies to limit bite sizes to those that would fit in the mouth $(C, D)$. Other species were intermediate to those shown here.

studies never approached $R_{\max }$ because bite sizes consumed in those studies severely limited intake rate (Table 4). When we used the bite sizes observed in previous studies to drive our functional response model (Eq. 5), it accounted for $83 \%$ of the variation in intake rate for a broad array of herbivores. Our model tended to overestimate intake rate (intercept $<0$ ), yet it achieved a level of generality not exhibited by other models of herbivore functional response.

We find this generality somewhat surprising because we believed that several factors inherent to the design of our experiments should limit their applicability. We

TABLE 3. Chewing frequency and chewing effort for herbivores consuming fresh alfalfa.

\begin{tabular}{|c|c|c|c|c|}
\hline \multirow[b]{2}{*}{ Species } & \multicolumn{2}{|c|}{ Chews/min } & \multicolumn{2}{|c|}{ Chews/g intake } \\
\hline & $\overline{\bar{X}}$ & SD & $\bar{X}$ & SD \\
\hline Lemming & 474 & 51.4 & 3590 & 447 \\
\hline Prairie dog & 276 & 21.4 & 342 & 46.4 \\
\hline Rabbit & 282 & 17.6 & 247 & 48.1 \\
\hline Peccary & 121 & 3.3 & 34.2 & 7.31 \\
\hline White-tailed deer (fawn) & 145 & 8.2 & 17.9 & 1.93 \\
\hline White-tailed deer (adult) & 101 & 0.5 & 7.97 & 2.04 \\
\hline Axis deer & 121 & 6.3 & 11.56 & 1.82 \\
\hline Caribou & 150 & 2.1 & 7.37 & 0.52 \\
\hline Grizzly bear & 139 & 2.4 & 4.28 & 0.73 \\
\hline Elk & 112 & 8.4 & 3.33 & 0.35 \\
\hline Moose & 117 & 9.6 & 5.73 & 1.42 \\
\hline Horse & 91 & 7.3 & 2.67 & 0.43 \\
\hline Cow & 67 & 2.1 & 0.85 & 0.24 \\
\hline
\end{tabular}




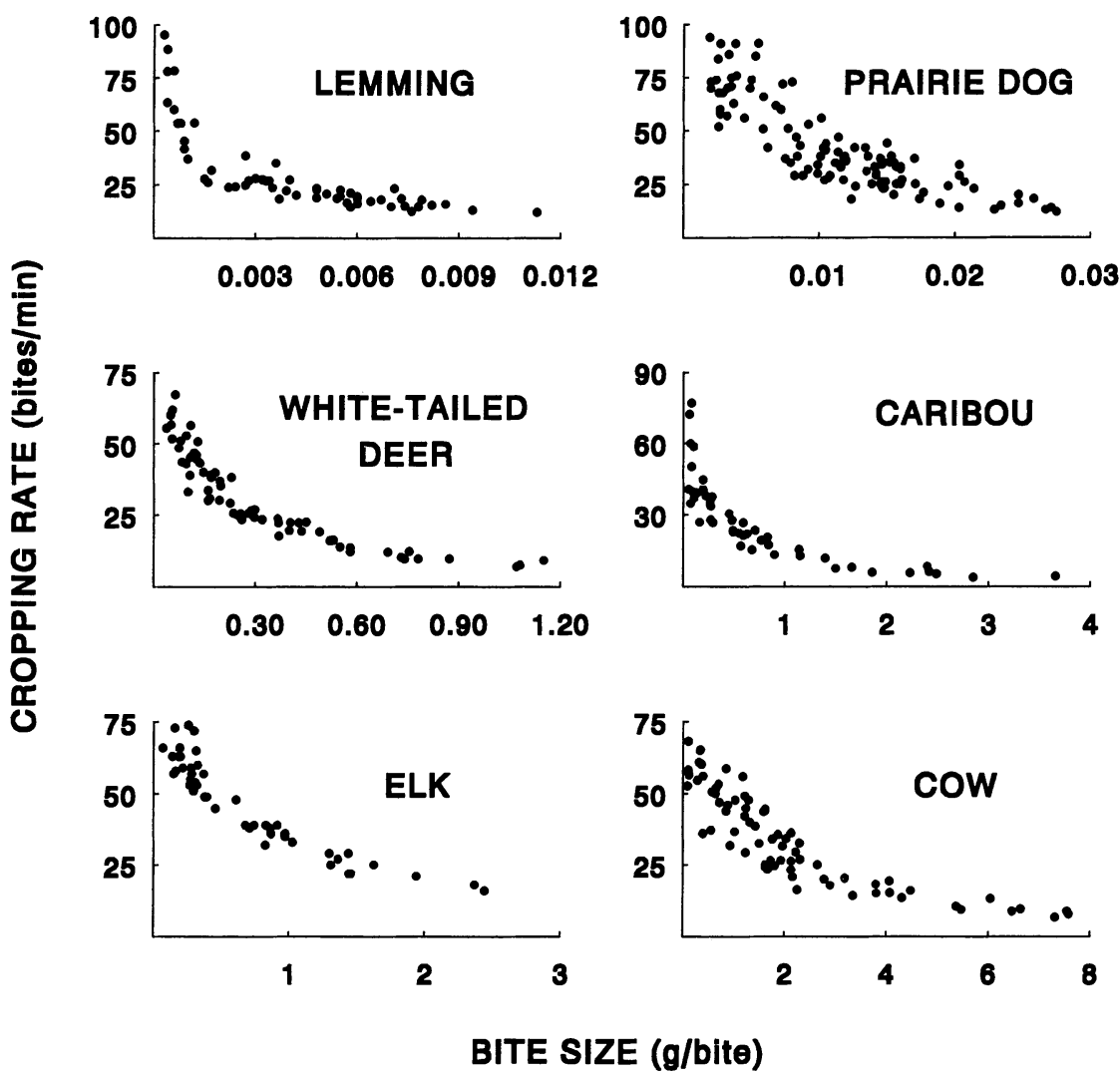

FIG. 3. Cropping rate declined nonlinearly with increased bite size for all species, as predicted by Eq. 4. We show six representative species differing in body size and feeding style; other species show similar trends.

offered each animal a homogeneous patch of high-quality, low-fiber forage (fresh alfalfa). In so doing, we eliminated characteristics that could potentially reduce intake rate or feeding efficiency, such as high fiber levels

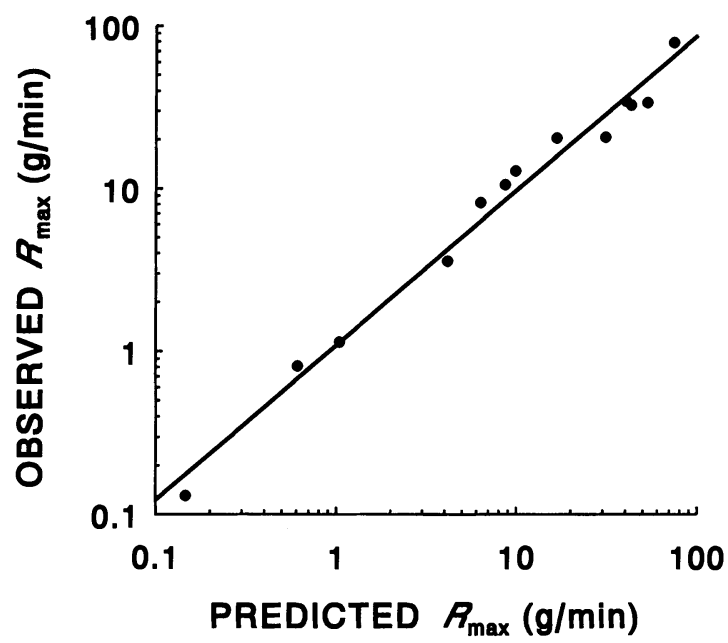

FIG. 4. Predicted maximum intake rate $\left(R_{\max }\right)$ was highly correlated with observations based on chewing rate and chewing effort. Best fit to line shown is $\log _{10} y=0.039+0.948$ $\log _{10} x\left(r^{2}=0.98, P<.001\right)$. For untransformed data, $y=$ $0.432+0.87 x\left(r^{2}=0.91, P<.001\right)$.
(Balch 1971, Spalinger et al. 1988), a densely branched plant architecture (McNaughton 1984), or the inclusion of inedible material in the feeding station (Arnold 1964, Bell 1970, McNaughton 1978). Moreover, because our objective was to test a model of mechanical (rather than volitional) controls on intake rate, we conducted trials with highly motivated, hungry animals that were most likely to maximize short-term intake rate (Demment and Greenwood 1988, Dougherty et al. $1989 c$ ). We caution that in some situations, these influences may strongly impact intake rate (Dunham 1980, Arthur 1984) and may limit the utility of our model.

Temporal scale is central to understanding an animal's functional response. We focused on instantaneous intake rate and the processes that control it. Because animals typically consumed our hand-assembled patches in a systematic manner, there was essentially no patch depletion during the course of a measurement; the distance between bites was the same for the first two bites of a trial and the last two. In addition, because the mechanical processes responsible for the functional response operate on a time scale of seconds or minutes, we limited the length of feeding trials. Studies of the relationship between food availability and intake rate of herbivores have focused on different time 
scales, ranging from periods of a few minutes (this study, Trudell and White 1981, Black and Kenney 1984, Hudson and Watkins 1986, Spalinger et al. 1988), 10's of minutes (Batzli et al. 1981, Milne et al. 1982, Lundberg and Danell 1990), one to several hours (Allden and Whittaker 1970, Short 1986, Lundberg 1988, Dougherty et al. 1989a), or $\geq 24 \mathrm{~h}$ (Chacon and Stobbs 1976, Jamieson and Hodgson 1979, Hodgson and Jamieson 1981, Short 1985). Direct comparisons between these studies are difficult because constraints imposed by short-duration mechanical processes, such as cropping and chewing time, are confounded with processes that operate over longer time frames, such as digestion, gut fill, or satiety (e.g., Suzuki et al. 1969, Dougherty et al. 1989c). The interaction among processes regulating intake over different time scales offers an important, unresolved question in foraging ecology.

Our results suggest that bite size is a useful predictor of short-term intake rate of herbivores (Figs. 1 and 5). Traditionally, biomass density (in grams per square metre) has been used for this purpose. The use of biomass density to predict intake can be traced to the historical predominance of studies of domestic ruminants feeding in grasslands (reviewed by Hodgson 1985 and Forbes 1988). In habitats with a relatively simple structure, such as grass swards, there is a strong correlation between bite size and biomass density (Stobbs 1975, Black and Kenney 1984, Hudson and Nietfeld 1985, Hudson and Watkins 1986, Penning et al. 1991), and consequently either measure can effectively be used to predict intake rate of grazers. However, a bite cropped by a browser typically consists of a leaf, or a twig with a few leaves. Hence, the size of bites cropped by browsers is often controlled by leaf size. When leaf size con-

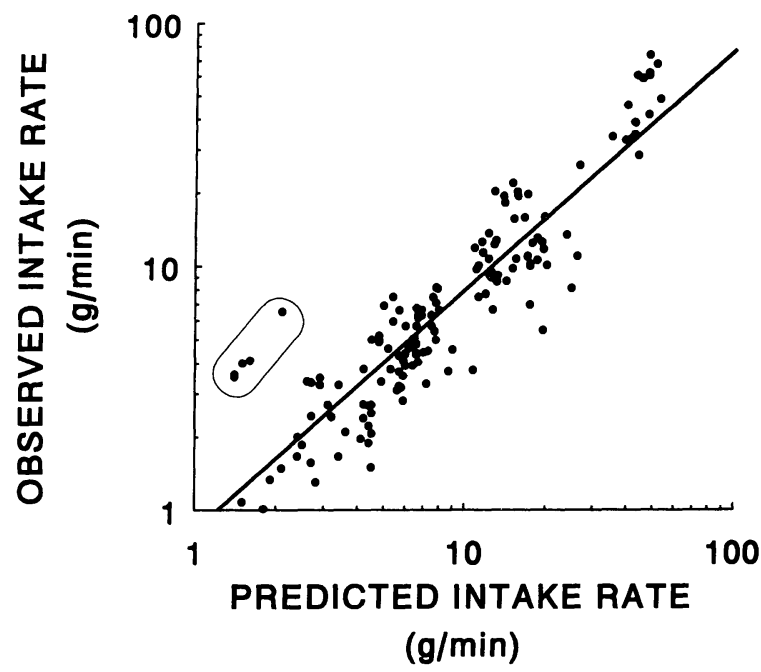

Fig. 5. Intake rate predicted by our model (Eq. 5) was highly correlated with observations of intake from other studies (Eq. 5, $n=153, \log _{10} y=-0.085+0.988 \log _{10} x, r^{2}=$ $0.83, P<.001$, for untransformed data $y=-2.09+1.07 x$, $\left.r^{2}=0.86, P<.001\right)$. Species plotted are mule deer, Sitka black-tailed deer, impala, elk, bison, reindeer, moose, sheep, and cattle. All data points except those circled were obtained by direct visual counts of cropping movements of the jaw. Circled points were obtained indirectly using a pneumatic device (Trudell and White 1981) that may count noncropping jaw movements. Data from Allden and Whittaker (1970), Collins et al. (1978), Trudell and White (1981), Dunham (1980), Arthur (1984), Wickstrom et al. (1984), Hudson and Nietfeld (1985), Renecker and Hudson (1986), Hudson and Frank (1987), Spalinger et al. (1988), Flores et al. (1989a, $b$ ), Dougherty et al. $(1989 b, 1990)$, Penning et al. (1991), and Watkins et al. (1991).

TABLE 4. Maximum intake rates of mammalian herbivores consuming fresh forages.

\begin{tabular}{|c|c|c|c|c|c|}
\hline Species & $\begin{array}{c}\text { Body } \\
\text { mass (kg) }\end{array}$ & $\begin{array}{c}\text { Bite } \\
\text { size }(g)\end{array}$ & $\begin{array}{l}\text { Intake rate } \\
(\mathrm{g} / \mathrm{min})\end{array}$ & $\begin{array}{c}\text { Forage or } \\
\text { habitat }\end{array}$ & Source \\
\hline Bank vole & $0.04^{*}$ & & 0.012 & willow shoots & Lundberg 1988 \\
\hline Brown lemming & 0.05 & & 0.11 & arctic sod & Batzli et al. 1981 \\
\hline Domestic lamb & $40 \dagger$ & 0.20 & 5.0 & service-berry shrub & Flores et al. $1989 a$ \\
\hline Impala & 40 & 0.37 & 7.48 & Diospyros lycioides & Dunham 1980 \\
\hline Ewe & $40 \dagger$ & 0.168 & 5.7 & perennial ryegrass & Penning et al. 1991 \\
\hline Sheep & 41.5 & & 6 & Kikuyu grass & Black and Kenney 1984 \\
\hline Mule deer & 42 & 0.35 & 6 & mixed diet & Wickstrom et al. 1984 \\
\hline Sheep & 43 & 0.4 & 7.5 & ryegrass & Allden and Whittaker 1970 \\
\hline Black-tailed deer & 48 & 0.28 & 7.5 & Rubus spectabilis & Spalinger et al. 1988 \\
\hline Mule deer & 60 & & 3.3 & clear-cut forest & Collins and Urness 1983 \\
\hline Reindeer & 70 & & 12.7 & Pedicularis landgsorfii & Trudell and White 1981 \\
\hline Elk & $225 \dagger$ & 0.36 & 12.6 & grass sward & Hudson and Nietfeld 1985 \\
\hline Elk & 160 & 1.6 & 20 & mixed diet & Wickstrom et al. 1984 \\
\hline Elk & 231 & & 17.2 & clear-cut forest & Collins and Urness 1983 \\
\hline Elk & $250 \dagger$ & 0.5 & 22.5 & wet meadow & Collins et al. 1978 \\
\hline Elk & $250 \dagger$ & 0.7 & 21 & cured pasture & Hudson and Watkins 1986 \\
\hline Moose & 340 & 1.2 & 22.5 & summer forages & Renecker and Hudson 1986 \\
\hline Moose & $350^{*}$ & & 29 & birch trees & Åström et al. 1990 \\
\hline Moose & 360 & & 16.7 & deciduous leaves & Belovsky and Jordan 1978 \\
\hline Cow & 471 & 1.46 & 49 & fresh alfalfa & Dougherty et al. $1989 c$ \\
\hline Cow & $400+$ & 1.22 & 74.1 & open grassland & Arthur 1984 \\
\hline
\end{tabular}

* Nowak and Paradiso 1983.

$\dagger$ Personal estimate. 
trols bite size, bite size and biomass density are uncoupled (Spalinger et al. 1988, Spalinger and Hobbs 1992), and the predictive power of biomass density is lost (Trudell and White 1981, Wickstrom et al. 1984, Renecker and Hudson 1986, Spalinger et al. 1988). The failure of biomass density to provide general predictions of herbivore functional response emphasizes the need for mechanistic models that respond to the variety of foraging situations encountered by herbivores. We think that a better understanding of the features of plants and animals that control bite size is central to this development.

\section{Relationship to theory on functional response}

Most contemporary models of functional response represent foraging by predators. Because herbivores encounter foraging situations that differ markedly from those confronted by predators, traditional functional response models often fail to describe processes regulating intake rate by herbivores. For example, Holling's disc equation and the random parasitoid model require that searching for food and handling it occur as mutually exclusive events (Holling 1959, Rogers 1972). Asymptotic forms result in these models because searching competes with handling, i.e., the predator can allocate its time to one activity or the other, but not both simultaneously. In addition, functional response models designed for predators predict the number of similar-sized prey captured per unit time (Holling 1959, Rogers 1972, Stephens and Krebs 1986, Trexler et al. 1988, Abrams 1990). But "prey" size for herbivores varies dynamically; it can change by more than an order of magnitude even when animals are feeding on the same plant species (Fig. 2). Moreover, while predators must often reside at a prey item to consume it, herbivores can process bites from one plant as they move through the environment looking for another. Because searching and handling overlap in time, searching does not compete with handling when plants are sufficiently concentrated in space.

Our model is a Michaelis-Menten function that can be shown to be algebraically identical to the disc equation of Holling (1965) under the assumption that the cropping rate is a linear function of bite (i.e., prey) density (Real 1977). However, this assumption clearly does not hold for herbivores feeding in food-concentrated patches. Cropping rates changed over an order of magnitude even when the density of plants (or bites) offered to animals was held constant (Fig. 3). Thus, although our model is mathematically consistent with the disc equation, it is functionally different.

The primary difference between our model and previous functional response models follows from assumptions of the foraging process. Our experiments substantiate the idea that competition between cropping and chewing regulate the instantaneous intake rate of herbivores feeding in food-concentrated patches. These results are analogous to the competition between searching and handling in predator-based models; the herbivore can allocate its time to cropping or to chewing but not both simultaneously (Fig. 3, also see Ardran et al. 1958, Greaves 1978, Fortelius 1985). Competition between cropping and chewing does not require that an herbivore finish chewing one bite before cropping another, i.e., at any instant an animal may be chewing several bites at once. But, this does mean that the overall cropping rate is limited by the chewing rate, i.e., the rate of input to the mouth cannot exceed the rate of output. Large bites require longer chewing times than small ones and, hence, depress cropping rate through competition for jaw movements. We surmise from our experiments in food-concentrated patches that the mechanism represented in the functional response models of Spalinger and Hobbs (1992) and Laca and Demment (1992) faithfully represents these features of short-term regulation of intake. We suggest that the fidelity of the model to this mechanism explains its broad applicability to herbivores of vastly different body size and feeding style (Figs. 1 and 5).

Our observations allow us to reject the hypothesis that input to the mouth regulates maximum intake rate in mammalian herbivores. Clutton-Brock and Harvey (1983) proposed that because buccal capacity determines bite size, maximum intake rate is proximally limited by the volume of the mouth. They suggested that intake rate responds directly to the amount of food consumed by each bite, because cropping rate is relatively constant. Their hypothesis leads to predictions inconsistent with our observations. First, it suggests a linear increase of intake rate with bite size (i.e., Eq. 5), that is, a linear Type I as opposed to an asymptotic Type II functional response. In contrast, we observed a nonlinear, asymptotic response of intake rate to bite size (Fig. 1). Second, Clutton-Brock and Harvey (1983) suggested that cropping rate is insensitive to bite size, but we observed an inverse relationship between cropping rate and bite size (Fig. 2). The close correspondence of our observed maximum intake rate and that predicted from chewing rate and chewing effort (Fig. 4) lends strong support to the idea that the most important determinant of intake rate is processing capacity. Hence, we conclude that although cropping rate is proximally responsible for intake regulation, processing bites for swallowing ultimately controls intake by regulating cropping rate.

Identifying how cropping and chewing compete to regulate intake rate provides a foundation for predicting how plant morphology and structure can influence foraging strategies of herbivores. Plant fibrosity (Balch 1971) or cell wall thickness (Spalinger et al. 1988) will reduce the processing rate $\left(R_{\max }\right)$ by increasing chewing effort (Spalinger et al. 1988), but may have little or no direct effect on cropping time $(\bar{h})$. On the other hand, we postulate that reductions in intake rate related to spinescence (Dunham 1980, Cooper and Owen-Smith 1986) or changes in plant morphology (McNaughton 
1984) result from an increase in the time required to crop bites $(\bar{h})$, but are unrelated to processing rate $\left(R_{\max }\right)$. Because cropping time is relatively more important to functional response as bite size diminishes, we expec that plants with small bites (e.g., small leaves) will be much more effectively protected by mechanical structures than plants with large bites. When leaves are large, more time is spent chewing and features that increase chewing effort (e.g., lignin) will have more impact on intake rate. These factors also emphasize the limitations on inferences offered by our data. We conducted trials with alfalfa plants in peak condition, with very high palatability and relatively low fiber contents. Therefore, our measures of cropping rate, chewing effort, and the resulting $R_{\max }$ are likely to differ from those obtained in other settings.

Although previous models of herbivore functional response have provided useful statistical descriptions of observations of intake rate (e.g., Allden and Whittaker 1970, Wickstrom et al. 1984, Hudson and Watkins 1986, Hudson and Frank 1987, Lundberg and Danell 1990), they failed to provide testable hypotheses on the processes regulating intake. In contrast, our model describes a specific mechanism. Our tests of the model offer evidence that this mechanism, competition between cropping and processing, is responsible for Type II functional responses frequently observed for herbivores feeding in food-concentrated patches.

\section{ACKNOWLEDGMENTS}

We thank the many technicians who assisted with feeding trials and animal care, and especially Mandy Kotzman anc Mark Shipley for their help on many levels. We are grateful to Dr. C. T. Robbins for graciously sharing his animals and facilities at Washington State University. Dr. John Fryxell provided helpful suggestions on revising the manuscript. This study was supported by United States National Science Foundation grants BSR-9006738/9007882, the Colorado Division of Wildlife, and the Texas Agricultural Experiment Station.

\section{LITERATURE CITED}

Abrams, P. A. 1990. The effects of adaptive behavior on the type-2 functional response. Ecology 71:877-885.

$\rightarrow$ Allden, W. G., and I. A. McD. Whittaker. 1970. The determinants of herbage intake by grazing sheep: the interrelationship of factors influencing herbage intake and availability. Australian Journal of Agricultural Research 21:755766.

Ardran, G. M., F. H. Kemp, and W. D. L. Ride. 1958. A radiographic analysis of mastication and swallowing in the domestic rabbit: Oryctolagus cuniculus (L). Proceedings of the Zoological Society, London 130:257-274.

Arnold, G. W. 1964. Factors within plant associations affecting the behavior and performance of grazing animals. Pages 133-154 in D. J. Crisp, editor. Grazing in terrestrial and marine environments. Blackwell Scientific, Oxford, England.

Arthur, R. L. 1984. Plant community and forage preferences of cattle on native aspen parkland range. Thesis. University of Alberta, Edmonton, Alberta, Canada.

$\rightarrow$ Åström, M., P. Lundberg, and K. Danell. 1990. Partial prey consumption by browsers: trees as patches. Journal of Animal Ecology 59:287-300.
Balch, C. C. 1971. Proposal to use time spent chewing as an index of the extent to which diets for ruminants possess the physical property of fibrousness characteristic of roughness. British Journal of Nutrition 26:383-392.

Batzli, G. O., H.-J. G. Jung, and G. Guntenspergen. 1981. Nutritional ecology of microtine rodents: linear foragingrate curves for brown lemmings. Oikos 37:112-116.

Bell, R. H. V. 1970. The use of the herb layer by grazing ungulates in the Serengeti. Pages 111-124 in A. Watson, editor. Animal populations in relation to their food resources. Symposium of the British Ecological Society Number 10. Blackwell Scientific, Oxford, England.

Belovsky, G. E., and P. A. Jordan. 1978. The time-energy budget of a moose. Theoretical Population Biology 14:76104.

Black, J. L., and P. A. Kenney. 1984. Factors affecting diet selection by sheep. II. Height and density of pasture. Australian Journal of Agricultural Research 35:565-578.

Burlison, A. J., J. Hodgson, and A. W. Illius. 1991. Sward canopy structure and the bite dimensions and bite weight of grazing sheep. Grass and Forage Science 46:29-38.

Caughley, G. 1982. Vegetation and the dynamics of modelled grazing systems. Oecologia (Berlin) 54:309-312.

Chacon, E., and T. H. Stobbs. 1976. Influence of progressive defoliation of a grass sward on the eating behaviour of cattle. Australian Journal of Agricultural Research 27:709727.

Clutton-Brock, T. H., and P. Harvey. 1983. The functional significance of variation in body size among mammals. Pages 632-663 in J. F. Eisenberg and D. G. Kleinman, editors. Advances in the study of mammalian behavior. Special Publication of the American Society of Mammalogy, Shippensburg State College, Shippensburg, Pennsylvania, USA.

$\rightarrow$ Collins, W. B., and P. J. Urness. 1983. Feeding behavior and habitat selection of mule deer and elk on northern Utah summer range. Journal of Wildlife Management 47:646663.

Collins, W. B., P. J. Urness, and D. D. Austin. 1978. Elk diets and activities on different lodgepole pine habitat segments. Journal of Wildlife Management 42:799-810.

Cooper, S. M., and N. Owen-Smith. 1986. Effects of plant spinescence on large mammalian herbivores. Oecologia (Berlin) 68:446-455.

Demment, M. W., and G. B. Greenwood. 1988. Forage ingestion: effects of sward characteristics and body size. Journal of Animal Science 66:2380-2392.

Dougherty, C. T., N. W. Bradley, P. L. Cornelius, and L. M. Lauriault. 1989a. Accessibility of herbage allowance and ingestive behavior of beef cattle. Applied Animal Behavioral Science 23:87-97.

Dougherty, C. T., N. W. Bradley, P. L. Cornelius, and L. M. Lauriault. $1989 \mathrm{~b}$. Ingestive behaviour of beef cattle offered different forms of lucerne (Medicago sativa L.). Grass and Forage Science 44:335-342.

Dougherty, C. T., M. Collins, N. W. Bradley, P. L. Cornelius, and L. M. Lauriault. 1990. Moderation of ingestive behaviour of beef cattle by grazing-induced changes in lucerne swards. Grass and Forage Science 45:135-142.

Dougherty, C. T., P. L. Cornelius, N. W. Bradley, and L. M. Lauriault. 1989c. Ingestive behavior of beef heifers within grazing sessions. Applied Animal Behavioral Science 23: 341-351.

Dunham, K. M. 1980. The feeding behavior of a tame impala. African Journal of Ecology 18:253-257.

Edelstein-Keshet, L. 1986. Mathematical theory for plantherbivore systems. Journal of Mathematical Biology 24: 25-58.

Elsen, J. M., D. Wallach, and J. L. Charpenteau. 1988. The calculation of herbage intake of grazing sheep: a detailed 
comparison between models. Agricultural Systems 26:123160.

Flores, E. R., F. D. Provenza, and D. F. Balph. 1989a. Role of experience in the development of foraging skills of lambs browsing the shrub serviceberry. Applied Animal Behavioral Science 23:271-278.

Flores, E. R., F. D. Provenza, and D. F. Balph. 1989b. Relationship between plant maturity and foraging experience of lambs grazing hycrest crested wheatgrass. Applied Ani mal Behavioral Science 23:279-284.

Forbes, T. D. A. 1988. Researching the plant-animal interface: the investigation of ingestive behavior in grazing animals. Journal of Animal Science 66:2369-2379.

Fortelius, M. 1985. Ungulate cheek teeth: development, functional, and evolutionary interrelations. Acta Zoologica Fennica 180:1-76.

Greaves, W. S. 1978. The jaw lever system in ungulates: a new model. Journal of Zoology, London 184:271-285.

Grenfell, B. T. 1992. Parasitism and the dynamics of ungulate grazing systems. American Naturalist 139:907-929.

Hassell, M. P. 1978. The dynamics of arthropod predatorprey systems. Princeton University Press, Princeton, New Jersey, USA.

Hodgson, J. 1985. The control of herbage intake in the grazing ruminant. Proceedings of the Nutrition Society 44 339-346.

Hodgson, J., and W. S. Jamieson. 1981. Variations in herbage mass and digestibility, and the grazing behaviour and herbage intake of adult cattle and weaned calves. Grass and Forage Science 36:39-48.

Holling, C. S. 1959. Some characteristics of simple types of predation and parasitism. Canadian Entomologist 41:385398.

- 1965. The functional response of predators to prey density and its role in mimicry and population regulation. Memoirs of the Entomological Society of Canada 45:1-60.

$\rightarrow$ Hudson, R. J., and S. Frank. 1987. Foraging ecology of bison in aspen boreal habitats. Journal of Range Management 40: 71-75.

$\rightarrow$ Hudson, R. J., and M. T. Nietfeld. 1985. Effect of forage depletion on the feeding rate of wapiti. Journal of Range Management 38:80-82.

Hudson, R. J., and W. G. Watkins. 1986. Foraging rates of wapiti on green and cured pastures. Canadian Journal of Zoology 64:1705-1708.

Illius, A. W., and I. J. Gordon. 1987. The allometry of food intake in grazing ruminants. Journal of Animal Ecology 56: 989-999.

Jackson, D. A., and K. M. Somers. 1991. The spectre of "spurious" correlations. Oecologia (Berlin) 86:147-151.

Jamieson, W. S., and J. Hodgson. 1979. The effect of daily herbage allowance and sward characteristics upon the ingestive behaviour and herbage intake of calves under stripgrazing management. Grass and Forage Science 34:261271.

$\rightarrow$ Janis, C. M., and D. Ehrhardt. 1988. Correlation of relative muzzle width and relative incisor width with dietary preference in ungulates. Zoological Journal of the Linnean Society 92:267-284.

Kenney, B. C. 1991. Comments on "Some misconceptions about the spurious correlation problem in the ecological literature" by Y. T. Prairie and D. F. Bird. Oecologia (Berlin) 86:152.

Laca, E. A., and M. W. Demment. 1992. Modelling intake of a grazing ruminant in a heterogeneous environment. Pages 57-76 in T. Okubo, B. Hubest, and G. Arnold, editors. Proceedings of the International Symposium on Vegetation-Herbivore Relationships. Academic Press, New York, New York, USA

Laca, E. A., E. D. Ungar, N. Seligman, and M. W. Demment. 1992. Effects of sward height and bulk density on bite dimensions of cattle grazing homogeneous swards. Grass and Forage Science 47:91-102.

Lundberg, P. 1988. Functional response of a small mammalian herbivore: the disc equation revisited. Journal of Animal Ecology 57:999-1006.

Lundberg, P., and M. Åström. 1990. Functional response of optimally foraging herbivores. Journal of Theoretical Biology 144:367-377.

Lundberg, P., and K. Danell. 1990. Functional response of browsers: tree exploitation by moose. Oikos 58:378-384.

McNaughton, S. J. 1978. Serengeti ungulates: feeding selectivity influences the effectiveness of plant defense guilds. Science 199:806-807.

- 1984. Grazing lawns: animals in herds, plant form and coevolution. American Naturalist 124:863-886.

Milne, J. A., J. Hodgson, R. Thompson, W. G. Souter, and G. T. B. Barthram. 1982. The diet ingested by sheep grazing swards differing in white clover and perennial ryegrass content. Grass and Forage Science 37:209-218.

Motulsky, H. J., and L. A. Ransnas. 1987. Fitting curves to data using nonlinear regression: a practical and nonmathematical review. FASEB Journal 1:365-374.

Nowak, R. M., and J. L. Paradiso. 1983. Walker's mammals of the world. Fourth edition. Johns Hopkins University Press, Baltimore, Maryland, USA

Owen-Smith, N., and P. Novellie. 1982. What should a clever ungulate eat? American Naturalist 119:151-178

Penning, P. D., A. J. Parsons, R. J. Orr, and T. T. Treacher. 1991. Intake and behaviour responses by sheep to changes in sward characteristics under continuous stocking. Grass and Forage Science 46:15-28.

Prairie, Y. T., and D. F. Bird. 1989. Some misconceptions about the spurious correlation problem in the ecological literature. Oecologia (Berlin) 81:285-288.

Pyke, G. H. 1984. Optimal foraging theory: a critical review. Annual Review of Ecology and Systematics 15:523-575.

Real, L. A. 1977. The kinetics of functional response. American Naturalist 111:289-300.

Renecker, L. A., and R. J. Hudson. 1986. Seasonal foraging rates of free-ranging moose. Journal of Wildlife Management 50:143-147.

Rogers, D. 1972. Random search and insect population models. Journal of Animal Ecology 41:369-383.

SAS. 1988. SAS/STAT user's guide. Release 6.03. SAS Institute, Cary, North Carolina, USA.

Schoener, T. W. 1971. Theory of feeding strategies. Annual Review of Ecology and Systematics 2:369-404.

Short, J. 1985. The functional response of kangaroos, sheep and rabbits in an arid grazing system. Journal of Applied Ecology 22:435-447.

. 1986. The effect of pasture availability on food intake, species selection and grazing behaviour of kangaroos. Journal of Applied Ecology 23:559-571.

Sokal, R. R., and F. J. Rohlf. 1981. Biometry. Second edition. Freeman, San Francisco, California, USA.

Solomon, M. E. 1949. The natural control of vertebrate populations. Journal of Animal Ecology 18:1-35.

Spalinger, D. E., T. A. Hanley, and C. T. Robbins. 1988. Analysis of the functional response in foraging in the Sitka black-tailed deer. Ecology 69:1166-1175.

Spalinger, D. E., and N. T. Hobbs. 1992. Mechanisms of foraging in mammalian herbivores: new models of functional response. American Naturalist 140:325-348.

Stephens, D. W., and J. R. Krebs. 1986. Foraging theory. Princeton University Press, Princeton, New Jersey, USA.

Stobbs, T. H. 1973. The effect of plant structure on the intake of tropical pastures. I. Variation in the bite size of grazing cattle. Australian Journal of Agriculture 24:809819.

1975. The effect of plant structure on the intake of tropical pasture. III. Influence of fertilizer nitrogen on the 
size of bite harvested by jersey cows grazing Setaria anceps cv. Kazungula swards. Australian Journal of Agriculture 26:997-1007.

Suzuki, S., H. Fujita, and Y. Shinde. 1969. Change in rate of eating during a meal and the effect of the interval between meals on the rate at which cows eat roughages. Animal Production 11:29-41.

Trexler, J. C., C. E. McCulloch, and J. Travis. 1988. How can the functional response best be determined? Oecologi (Berlin) 76:206-214.

Trudell, J., and R. G. White. 1981. The effect of forage structure and availability on food intake, biting rate, bite size, and daily feeding time of reindeer. Journal of Applied Ecology 18:63-81.
Ungar, E. D., and I. Noy-Meir. 1988. Herbage intake in relation to availability and sward structure: grazing processes and optimal foraging. Journal of Applied Ecology 25:1045-1062.

Watkins, W. G., R. J. Hudson, and P. L. J. Fargey. 1991. Compensatory growth of wapiti (Cervus elaphus) on aspen parkland ranges. Canadian Journal of Zoology 69:16821688.

Wickstrom, M. L., C. T. Robbins, T. A. Hanley, D. E. Spalinger, and S. M. Parish. 1984. Food intake and foraging energetics of elk and mule deer. Journal of Wildlife Management 48:1285-1301. 